\author{
MICHAŁ HANCZAKOWSKI \\ (D) https://orcid.org/0000-0001-5603-0661 \\ Uniwersytet Palackiego \\ Ołomuniec
}

\title{
Czescy emigranci i ich wpływ na polską kulturę przełomu XVI i XVII wieku na przykładzie rodziny Rybińskich i Jana Łasickiego
}

Czech emigrants and their influence on Polish culture of the late 16th early

17th century using the examples of the Rybiński family and of Jan Łasicki

\begin{abstract}
The paper presents selected aspects of the cultural influence of Czech emigration on the intellectual life of the Republic of Poland in the second half of the $16^{\text {th }}$ century and in the early $17^{\text {th }}$ century. The first part discusses the history of the Rybiński family and their literary achievements. The second part is dedicated to Jan Lasicki and to his version of the history of the Czech Brethren. Thus, the author of the paper attempts to show - using the examples of phenomena connected with the first and second wave of Czech emigration - how the presence of Czech emigrants influenced the Polish genological system of those times.
\end{abstract}

Key words: Jan Lasicki, Jan Rybiński, egodocuments, Polish-Czech relations

Czescy emigranci przybyli na tereny Rzeczpospolitej jako osoby wygnane z własnej ojczyzny z przyczyn religijnych. Pierwsza fala migracyjna miała miejsce w roku 1548, po wydaniu przez cesarza Fryderyka I dekretów, na mocy których przedstawiciele relatywnie nowego wyznania, jakim była Jednota Braci Czeskich, musieli bądź zmienić wyznanie, bądź też opuścić dotychczasowe miejsca pobytu. Mandaty te były konsekwencją zwycięstwa Habsburgów w I wojnie szmalkaldzkiej, w której liczni przedstawiciele szlachty tzw. nowoutrakwistycznej (czyli przyznającej się do konfesji zapoczątkowanej w latach 60. XV wieku przez Piotra Chelčickiego) wystapili przeciw Ferdynandowi. Pamiętać przy tym trzeba, że królewskie dekrety wyznaniowe miały relatywnie ograniczony zasięg - nie obejmowały szlachty 
utrakwistycznej (czyli tej, która swe protestanckie wyznanie wywodziła jeszcze od czasów husyckich i ustanowionych w pierwszej połowie wieku XV kompaktatów bazylejskich), zaś pod względem terytorialnym ograniczały się wyłącznie do majątków królewskich leżących w Czechach, co oznaczało, że nie dotyczyły one Moraw. Te wszystkie okoliczności sprawiły, że pierwsza fala emigracyjna była stosunkowo nieliczna - jak szacuje się dziś - liczyła około tysiąca osób. Ich celem były pierwotnie Prusy, w których reformacja zdobyła silne poparcie, w związku z czym Czesi mieli nadzieję, że bracia w reformacji życzliwie przyjmą prześladowaną mniejszość religijną. Po drodze leżała jednak Wielkopolska i konieczne było uzyskanie zgody na swobodne przejście przez tereny Rzeczpospolitej. W Wielkopolsce przedstawiciele braci czeskich zdobyli sympatię zarówno miejscowych władz, jak i większości ludzi. Jak zauważa Dworzaczkowa, Czesi dali się poznać jako uczciwi i zdolni rzemieślnicy (Dworzaczkowa 1997, 21), co pozostawiło zresztą ślad w polskiej literaturze - o braciach czeskich pisał Andrzej Frycz Modrzewski w dziele O poprawie Ržeczypospolitej, zauważając, że „zakazane są u nich wszelkie biesiady i pijatyki (...) i inne tego rodzaju postępki, z których pochodzi niezamierzone zło, mają bowiem Pismo przetłumaczone na swój język i wielu z nich umie czytać, a inni słuchają. Dlatego właśnie też są wśród nich znamienici rzemieślnicy różnego rodzaju” (cyt. za: Rott 2002, 10).

Jeszcze w tym samym roku bracia czescy musieli jednak opuścić Wielkopolskę pod naciskiem biskupa poznańskiego i administracji królewskiej (Dworzaczkowa 1997, 21). Część z nich szybko powróciła do Wielkopolski, na co wpływ miały zarówno gorsze niż się spodziewali warunki religijnej koegzystencji z luteranami na terenie Prus Królewskich, jak również postęp reformacji w Rzeczpospolitej i otwarta życzliwość niektórych polskich rodów szlacheckich - głównie Górków i Ostrorogów, w których majątkach mogli przebywać nawet wbrew naciskom biskupim i królewskim.

Druga fala czeskiej emigracji pojawiła się w Rzeczpospolitej pod wpływem wydarzeń związanych z początkową fazą wojny trzydziestoletniej. Porażka czeskich stanów w bitwie na Białej Górze i następujące po niej prześladowania ze strony katolików, których symbolem stała się egzekucja czeskiej szlachty protestanckiej na rynku praskiego Starego Miasta, doprowadziły do wydania przez władze habsburskie kilku aktów prawnych, które wymusiły drugą falę czeskiej emigracji. W roku 1624 z terenów cesarskich wygnano wszystkich niekatolickich duchownych. Trzy lata później ukazał się edykt, który nakazywał całej szlachcie przejście na katolicyzm lub przymusowa emigrację. Szacuje się, że w wyniku wprowadzenia tych przepisów decyzję 
o pozostaniu na terenach Rzeczpospolitej podjęło kilka tysięcy osób z terenu Czech (Dworzaczkowa 1997, 119), co było znaczną liczbą. W efekcie tych zjawisk druga fala emigracji czeskiej jest lepiej rozpoznawalna w polskiej świadomości historycznej i bardziej się w niej zapisała. Nie bez znaczenia jest przy tym fakt, że właśnie z nią wiąże się postać Jana Amosa Komeńskiego.

Zagadnienie dwóch fal czeskiej emigracji z perspektywy historycznej opisane jest dość dobrze, choć w wielu kwestiach dociekania historyków muszą bazować na skromnych materiałach źródłowych. Za prekursora badań poświęconych czeskiej emigracji w Rzeczpospolitej wypada uznać Józefa Łukaszewicza, który zajął się tą problematyką jeszcze na początku XIX wieku. Jak sam przyznawał, jego praca miała być zaledwie pierwszym krokiem do stworzenia dokładniejszego opisu dziejów polskiej reformacji; krokiem, którego głównym celem było wydanie materiałów związanych z

wyznaniem, które światu uczonemu i krajowi Komeniuszów, Johnstonów, Rybińskich, Turnowskich i tylu innych uczonych mężów wydało; (...) wyznania, które do wykształcenia dwóch języków słowiańskich, polskiego i czeskiego, i do rozszerzenia oświaty w narodzie naszym w wieku XVI znacznie przyłożyło (Lukaszewicz 1835, nlb.).

Praca Lukaszewicza - z dzisiejszej perspektywy już sama w sobie historyczna - wyrastała $z$ ducha dziewiętnastowiecznej fascynacji historią oraz w niemniejszym może stopniu również z fascynacji Słowiańszczyzną i czeskim odrodzeniem narodowym, o czym świadczy wzmianka o językach słowiańskich i jej wyraźnie panslawistyczny charakter wyrastający z tradycji badań filologicznych Jungmanna czy Lindego. Praca ta jednak zachowuje aktualność i dziś - przede wszystkim za sprawą edycji tekstów, które zostały bezpowrotnie utracone w czasie II wojny światowej. Edycje dokonane na użytek tej książki są w wielu przypadkach jedynymi śladami dawnych tekstów, nawet jeśli są to wersje pełne błędów i niespełniające wymogów dzisiejszych badań filologicznych.

Być może właśnie zaginięcie wielu dokumentów źródłowych stało się powodem, dla którego w badaniach śladów czeskiej emigracji na ziemiach Rzeczpospolitej przeważały ujęcia typowe dla historyków, nie zaś historyków literatury. Najważniejsze prace o takim właśnie historycznym charakterze ukazały się dzięki badaniom prowadzonym przez Jolantę Dworzaczkowa, szczególnie jej syntetyzująca praca Bracia çescy w Wielkopolsce w XVI 
iXVII wieku (1997). W swoich pracach badaczka nie ograniczała się jednak wyłącznie do opisu kwestii politycznych, etnicznych czy wyznaniowych. W osobnych studiach skupiała się również na zagadnieniach kulturowych, czego najlepszym przykładem mogą być jej badania poświęcone szkole leszneńskiej (2003) czy szkole w Koźminku (1995, 145-56).

Nad kwestiami kulturowymi wypadło pochylić się również innej historyczce, której badania związane były z kwestią relacji polsko-czeskich. Maria Sipayłł, skupiając się na problematyce wyznaniowej i na edycji synodów różnowierczych (por. Akta synodów różnowierczych w Polsce 1963-1997), z konieczności musiała sięgnąć również po pisma związane z Jednotą powstające na terenie Rzeczpospolitej. I chociaż jej prace skupiały się - podobnie jak w wypadku Dworzaczkowej - na opisie zjawisk, który wykorzystywal narzędzie typowe dla badań historycznych, to jednak doprowadziły do edycji wielu cennych tekstów dokumentujących życie kulturowej polskiej gałęzi Jednoty.

Nie sposób w tym miejscu nie wspomnieć o czeskich badaniach dotyczących tzw. exulantów, czyli wygnańców. Również w Czechach dominował historyczny model badania tych kwestii, czego najlepszym przykładem może być zachowująca aktualność - częściowo ze względu na brak nowszych ujęć - praca Jaroslava Bidly. Jego czteroczęściowe opracowanie zatytułowane Jednota bratrská v prvním vyhnanství ukazywało się od roku 1900, ale - podobnie jak prace Łukaszewicza - do dziś pozostaje w wielu miejscach aktualne (por. Bidlo 1900-1933).

Dominująca perspektywa historyczna w badaniach nad czeskimi migracjami zepchnęła niejako na drugi plan pytania o wpływy kulturalne, które są związane z obecnością czeskich emigrantów. Wydaje się to o tyle zrozumiałe, że - jak już wspomniano wcześniej - wiele źródeł piśmienniczych związanych $z$ tą emigracją zaginęło czy to w czasie wojen XVII wieku, czy też później - szczególnie w wieku XX. Nie oznacza to jednak, że badań nad dorobkiem literackim czeskich emigrantów w ogóle nie było. Pierwsze bardziej usystematyzowane prace z tego zakresu wyszły spod pióra Jana Ślizińskiego (1959). Studium to ma już dziś raczej wartość historyczna - ustalenia bazujące najczęściej na samych tylko kwerendach Estreichera nie spełniają dziś żadną miarą kryterium naukowości, bo też w kwestiach czeskich Estreicher mylił się dość często, a zjawisko to zasługiwałoby na osobne omówienie. Bezdyskusyjną zasługa Ślizińskiego pozostaje jednak fakt, że zdefiniował on jako osobne pole badawcze literaturę czeskiej emigracji, która przed nim studiowana była zazwyczaj fragmentarycznie i niesamodzielnie i, co za tym idzie, znikała w natłoku innych studiów poświęcanych polskiej reformacji. 
Kwestia emigracji czeskiej w Polsce w wieku XVI nie stała się przedmiotem analiz Henryka Gmiterka, którego opracowanie poświęcone polsko-czeskim związkom kulturalnym do dziś pozostaje niezastapionym źródłem wiedzy o tej epoce i związkach łączących ziemie polskie z czeskimi. Stało się tak, ponieważ badacz uznawał, że polsko-czeskie związki polityczne - a co za tym idzie również kulturalne - stają się znaczące dopiero w drugiej połowie wieku XVI, ze szczególnym uwzględnieniem ostatnich trzydziestu lat tego stulecia (Gmiterek 1989, 22-23), czyli okresu pierwszych elekcji, w których w odniesieniu do tronu polskiego pojawiały się kandydatury Habsburgów, reprezentowanych przez przedstawicieli czeskiej dyplomacji. Takie rozłożenie akcentów prowadziło lubelskiego badacza do skupienia się na zjawiskach późniejszych i takich postaciach, jak np. Szymon Teofil Turnowski. Zagadnienia konfesyjne przy przyjętej optyce przeważały nad kwestiami literackimi, co zresztą wydaje się zrozumiałe.

W efekcie opisanych zjawisk dopiero w roku 2002 polska historia literatury doczekała się nowocześniejszego ujęcia problematyki polsko-czeskich związków literackich w interesującym nas okresie. Monografia Dariusza Rotta skupiała się na postaciach wcześniej jedynie marginalnie pojawiających się w opracowaniach naukowych. U Rotta głównymi postaciami wpływającymi na specyfikę związków polsko-czeskich stali się: Piotr Wachenius, Anna Memorata, Krystyna Poniatowska i Daniel Vetter. Jednak tylko Piotra Wacheniusa można łączyć z pierwszą falą emigracji czeskiej, choć pewności w tym względzie nie ma, bo jak zauważa Rott o kontaktach z czeską reformacją „świadczyć mogą dość liczne czechizmy w jego utworach dostrzegane już wcześniej przez badaczy" (Rott 2002, 31), co jednak jest zbyt słabym dowodem na to, że Wachenius był w jakiś sposób powiązany z czeską emigracją. Postacie pozostałe to osoby żyjące już na przełomie XVI i XVII wieku, a więc dające się połączyć wyłącznie z pobiałogórską czeską emigracją.

Ten być może aż nazbyt rozbudowany wstęp konieczny był, by podkreślić, że kwestia emigracji czeskiej na ziemie Rzeczpospolitej nie jest zjawiskiem zbyt często poruszanym, a jeśli już, to wspomina się o niej zazwyczaj w kontekście postrzegania ówczesnej Rzeczpospolitej jako państwa bez stosów, czyli swoistego autostereotypu historycznego, którego funkcjonowanie wyraźnie uświadamiał sobie Janusz Tazbir, czyli autor słynnej książki Państwo bez stosów (2010). Jednakże obraz tolerancyjnego kraju, w którym czescy emigranci mogli się bez żadnych zastrzeżeń zatrzymać, wydaje się nazbyt jednowymiarowy. Dość powiedzieć, że przeciwko przedstawicielom Jednoty na ziemiach polskich zdecydowanie występowali przedstawiciele hierarchii ko- 
ścielnej, upatrując w przybyszach zagrożenia dla jedności religijnej. Nie sposób też nie zauważyć, że czescy różnowiercy nie mogliby pozostać na terenach Rzeczpospolitej, gdyby nie systemowe podstawy złotej wolności szlacheckiej, które pozwalały obejść antyheretyckie ustawodawstwo królewskie Zygmunta Augusta.

Pomimo tych wszystkich ograniczeń czescy emigranci odegrali w niektórych aspektach ważną rolę w polskim życiu intelektualnym. W niniejszym tekście chciałbym skupić się na dwóch przypadkach niezbyt oczywistego, ale jednoznacznie pozytywnego oddziaływania emigrantów. Przypadek pierwszy związany jest z pierwszą falą emigracyjna, przypadek drugi dotyczy emigracji pobiałogórskiej. Obydwa układają się w nieoczywisty obraz czeskich wpływów na polską kulturę literacką XVI i XVII wieku. Te dwa przypadki pokazują wyraźnie funkcjonowanie sieci swoistych powiązań personalnych i intelektualnych, która kształtowała nie tylko oblicze polskiej reformacji, ale również polskiej literatury przełomu XVI i XVII wieku, ale która z czasem uległa zapomnieniu. Znamienne jest przy tym, że o jej istnieniu mało się dziś mówi zarówno w badaniach polskich, jak i czeskich - w świadomości czeskiej owa sieć przynależy raczej do kultury polskiej, podczas gdy dla Polaków istnienie tego fenomenu ma znaczenie drugorzędne w porównaniu ze zjawiskami uznawanymi za typowe dla kultury państwa polsko-litewskiego. W efekcie niniejszy tekst jest tekstem o znikaniu tak autorów, jak i ich tekstów, a co za tym idzie - również o zanikaniu świadomości historycznej. Pośrednio zaś układa się on w opowieść o ujednolicaniu pod względem narodowościowym i konfesyjnym polskiej świadomości historycznej. W ostatniej zaś kolejności jest również rodzajem argumentu przemawiającego za tym, że emigracja jest z punktu widzenia życia kulturalnego zjawiskiem tyleż pożądanym - budującym różnorodność - co i zagrożonym ciagłym odrzuceniem.

Wśród pierwszych czeskich emigrantów, którzy trafili na ziemie polskie w połowie wieku XVI, odnajdujemy Jana Rybę. Jego działalność miała przede wszystkim charakter wyznaniowy - był on niestrudzonym pomocnikiem i towarzyszem Jerzego Izraela. Śladów jego obecności w polskim życiu literackim w zasadzie trudno się dziś doszukiwać, jeżeli pojawia się w zestawieniach bibliograficznych czy tekstach specjalistycznych, to wyłącznie jako ojciec Jana Rybińskiego. Pomija się przy tym zupełnie fakt, że Jan Ryba jest autorem jednej z najobszerniejszych i przy tym najciekawszych relacji podróżniczych powstałych w środowiskach braci czeskich.

W tym miejscu warto sobie uświadomić problemy, które związane są z tzw. piśmiennictwem prywatnym w epoce wczesnonowożytnej. Polskie li- 
teraturoznawstwo niechętnie sięgało po tego typu teksty. Już samo określenie „piśmiennictwo”, które miało je odróżniać od „literatury” brzmiało dość podejrzanie i świadczyło o lekkiej nucie pogardy. W efekcie teksty, takie jak diariusze, pamiętniki itp. były doceniane jako źródła historyczne, ale niezbyt często zastanawiano się nad ich wartościami estetycznymi. Fala zainteresowania takimi tekstami ujawniła się wyraźnie w momencie, gdy do obiegu naukowego Jacob Presser wprowadził pojęcie egodokumentu. O historii tego terminu i badań z nim związanych pisze szerzej Rudolf Dekker (2002), wypada jednak zauważyć, że w kontekście polskiego literaturoznawstwa badania te nałożyły się na badania Hanny Dziechcińskiej (2003) i Alojzego Sajkowskiego (2007).

Sam Jan Ryba w ramach misji ewangelizacyjnej i organizacyjnej braci czeskich pełnił funkcje pomocnicze w stosunku do Jerzego Izraela. Pamiętać przy tym należy, że jednym z powodów, dla których misją braci czeskich na terenach Rzeczpospolitej kierował Izrael, był fakt, że posługiwał się on językiem polskim w stopniu, który umożliwiał pracę z przedstawicielami polskiej szlachty. Tym bardziej więc zaskakuje, że autorem najobszerniejszej zachowanej relacji z tych działań, spisanej w języku polskim, jest nie sam Jerzy Izrael, a właśnie Jan Ryba. W roku 1556 odbyło się brackie poselstwo do szlachty małopolskiej, które miało ugruntować pozycję braci czeskich jako jednego z ważnych wyznań reformowanych - na tyle silnych, by zyskać wsparcie małopolskich mecenasów. Tekst Jana Ryby wszedł w skład materiałów archiwalnych Jednoty, dzięki temu zresztą przetrwał do naszych czasów jako część składowa synodaliów wydawanych przez Marię Sipayłło. Fakt ten wpłynął również na jego specyficzny kształt artystyczny. Tekst Ryby jest swoistym diariuszem - jednostką strukturyzującą całość są kolejne dni upływające na dyskusjach konfesyjnych. Dokumentacyjny charakter tej relacji wpływa również na jego retoryczne ukształtowanie - dominującą figurą jest w obrębie tekstu prozopopeja, w ramach której przytaczane są przede wszystkim wypowiedzi Jerzego Izraela. Wszystko to czyni z tej relacji jeden z ciekawszych przykładów wczesnego polskiego piśmiennictwa reformacyjnego, które praktycznie nigdy nie było przytaczane w kontekście literaturoznawczym. Wobec tego faktu nie dziwi, że sam Jan Ryba pozostaje dla polskiej historii literatury postacią znaną w zasadzie wyłącznie jako ojciec swojego syna.

Jan Rybiński jest niewatpliwie najbardziej w historii literatury polskiej znanym przedstawicielem rodziny Rybińskich, choć i w jego przypadku nie da się mówić o znajomości powszechnej, bowiem jeszcze w roku 1968 - kiedy 
ukazywało się drukiem pierwsze poważniejsze wydanie jego wierszy - autorzy owej edycji - Zbigniew Nowak i Anna Świderska - nazywali we wstępie Rybińskiego poeta zapomnianym (por. Nowak, Świderska 1968, VII). Polska twórczość Rybińskiego nie zyskała w literaturze przedmiotu zbyt wysokiej oceny. Jerzy Ziomek twórcę czeskiego pochodzenia określił niezbyt pochlebnie jako „poetę o dużej kulturze humanistycznej i niewielkim talencie” (Ziomek 1995, 369-370), zaś jego poezję określił jako

kontynuację liryki czarnoleskiej, choć kontynuację nawiną w tym sensie, że zachłanną w korzystaniu z zewnętrznych manifestacyjnych wskaźników kultury humanistycznej (...), które poetów mniejszego talentu prowadzi do banału i naruszenia równowagi między przedmiotem i tematem a stylem" (Ziomek 1995, 371).

Paradoksem jest, że polskie literaturoznawstwo podważało nie tylko wartość literacką dorobku Rybińskiego, ale nawet jego przynależność do kulturowego kręgu czeskich emigrantów. Józef Magnuszewski zadawał wręcz retoryczne pytanie, „w jakim stopniu należy jeszcze włączać tych [czyli J. Rybińskiego czy J. Turnowskiego - M.H] spolonizowanych pisarzy do związków polsko-czeskich" (1977, 125). Ta uwaga jednego z najwybitniejszych polskich bohemistów jest dość ważna. Stawia ona bowiem pytanie o tożsamość kulturową i narodową ówczesnych mieszkańców Rzeczpospolitej. W wypadku czeskich emigrantów i ich dzieci pytanie to wydaje się jeszcze bardziej złożone. Faktem bowiem jest, że większość tekstów czeskich emigrantów powstała w języku polskim lub łacińskim, co znajduje odzwierciedlenie i w niniejszym tekście. Omawiane w nim utwory literackie związane $z$ rodziną Rybińskich są tekstami polskimi i nie mają żadnych odpowiedników w literaturze czeskiej. Z kolei Łasicki pisze swój tekst dla europejskich elit intelektualnych, stąd użycie łaciny. Język czeski pojawia się tylko wyjątkowo i na pewno nie jest pierwszym wyborem - dotyczy to nawet pierwszego pokolenia czeskich emigrantów, jak to jest w wypadku Jana Ryby, który nie pozostawił po sobie żadnego tekstu w języku czeskim. Pamiętać jednak należy, że w okresie, o którym mowa, w ogóle trudno jest analizować to, czy język buduje jakieś poczucie tożsamości grupowej. Jeszcze zaś trudniej rozważać istnienie jakiejkolwiek tożsamości narodowej - o tej bowiem możemy mówić dopiero od XIX wieku.

Wracając zaś do kwestii literackich, wypada zauważyć, że to, co dla Ziomka stanowiło o niewielkiej wartości poezji tworzonych przez Rybińskiego, dla innych stawało się argumentem przemawiającym na jego korzyść. Silne 
oddziaływanie Kochanowskiego można bowiem oceniać jako epigonizm, inni badacze patrzyli jednak na jego twórczość jako sposób propagowania wzorców humanistycznych i promowanie polskiego modelu liryki renesansowej na terenach, gdzie polska kultura nie miała charakteru dominującego, jak to miało miejsce przykładowo na Pomorzu, o czym wspominali Nowak i Świderska (por. 1968, VIII). Rybiński był więc przydatny wówczas, gdy dało się go zaprezentować jako osobę przywiązaną do polonocentrycznego modelu kulturowego. Prawdopodobnie dlatego właśnie większy oddźwięk wśród badaczy literatury zyskała mowa Rybińskiego wygłoszona w Gimnazjum Akademickim w Toruniu w roku 1589, będąca pochwałą języka polskiego, niż to miało miejsce w wypadku utrzymanej w stylu Kochanowskiego liryki. Elwira Buszewicz określiła tę mowę jako „swoisty popis humanistycznej erudycji (od Homera do Kromera)”, w którym „wysławił Rybiński doskonałość i użyteczność języka polskiego" (Buszewicz 2015, 14). Erudycja humanistyczna traktowana jest więc jako atut w tych miejscach, w których da się użyć twórczości Rybińskiego jako argumentu przemawiającego na rzecz języka polskiego czy też polskiej kultury, w innych zaś przypadkach ta sama erudycja oceniana jest jako przejaw epigoństwa i braku talentu.

Twórczość Rybińskiego nie zachowała się w dobrym stanie i w tym sensie opowieść o nim jest opowieścią o zanikaniu kulturowej tradycji emigracyjnej. Polski zbiór Gésli różnorodnych ksiega przetrwał jako unikat Biblioteki Kórnickiej. Mniej szczęścia spotkało neolatynistyczny zbiór Ksiegi elegii podróżnych, które do naszych czasów dotrwały również w unikatowym, jednakże zdefektowanym egzemplarzu Biblioteki Jagiellońskiej, w którym brakuje zakończenia (Buszewicz 2015, 59). Ostatnim wreszcie tekstem, na który chciałbym zwrócić uwagę, jest autobiografia Jana Rybińskiego, która zachowała się w rękopisie Biblioteki Raczyńskich i wydana została przez Antoniego Danysza w roku 1922 w edycji, która z dzisiejszej perspektywy nie spełnia już warunków rzetelności naukowej.

W przypadku tego tekstu mamy do czynienia z sytuacja podobną do tej, która stała się udziałem egodokumentu Jana Ryby. Chodzi o autobiograficzny tekst wyrastający z tradycji sporów konfesyjnych, przy czym w wypadku tego utworu kwestia oceny artystycznej, klasyfikacji gatunkowej i szeroko rozumianej recepcji wydaje się jeszcze bardziej złożona niż przykład tekstu Jana Ryby. Dlaczego? Odpowiedzi mogą dostarczyć rozważania jednego z nielicznych badaczy staropolskiego dorobku pamiętnikarskiego - Alojzego Sajkowskiego. W swoim teoretycznym tekście o pamiętnikach polskich pomiędzy XVI a XVIII wiekiem zwrócił on uwagę na fakt, że wypowiedzi auto- 
biograficzne w obrębie staropolskiej literatury pamiętnikarskiej tworzą klasę tak różnorodną pod względem obejmowanego horyzontu czasowego, sposobu narracji, układu treści, że tylko z trudem można w odniesieniu do nich stosować jakiekolwiek kategoryzacje (Sajkowski 2007, 80). A wypada pamiętać, że rozważania swe badacz prowadzi w odniesieniu do okresu po roku 1572, czyli obejmującego już najprawdopodobniej autobiografię Rybińskiego, ale niemieszącego już w sobie tekstu Jana Ryby. O ile więc polskie literaturoznawstwo tworzyło kategoryzacje utworów dokumentujących podróże, o tyle w wypadku utworów autobiograficznych trudno nawet mówić o takich próbach. Wymusza to więc nie tylko posługiwanie się anachronicznym pojęciem egodokumentu, ale również wykraczanie poza teoretyczne ramy retoryki rozumianej jako teoria ówczesnej prozy (por. Ziomek 1990, 15). Nie można przy tym wattpić, że ewentualne naniesienie tych świadectw emigracyjnych pisarzy na mapę polskich egodokumentów epoki wczesnonowożytnej jeszcze bardziej zagmatwa jakiekolwiek próby usystematyzowania tego pola badawczego.

Warto też zwrócić uwagę na zakres ram czasowych, w których zazwyczaj rozpatruje się polską twórczość pamiętnikarską. We wstępie do swojej pracy poświęconej pamiętnikom Hanna Dziechcińska zauważyła, że

pamiętnikarz zaczynał mówić „o sobie samym”, stopniowo pojawiał się jako uczestnik zdarzeń, człowiek czujący i - co ważniejsze - ujawniający swoje uczucia. Poszerzał własną wizję świata, gdy stykał się z nowym krajobrazem, dziełami sztuki, odmienna przyroda, co prowadziło do kształtowania się literackiej kategorii opisu. Był to proces ewolucyjny, zapoczątkowany u schyłku XVII wieku $(2003,7)$.

Autobiograficzna twórczość Jana Rybińskiego wydaje się przeczyć takim próbom chronologicznego ujęcia egodokumentów. Uwzględnienie emigracyjnych egodokumentów pisanych przez czeskich emigrantów wymusiłoby przesunięcie początku ewolucji, o której wspomina Dziechcińska, już na połowę wieku XVI i powiązanie jej z kulturami obcymi, w tym wypadku z kultura czeska. Elegie podróżne syna czeskiego emigranta, jak również jego skrótowa autobiografia pokazują wyraźnie, że na terenach Rzeczpospolitej, podobnie zresztą jak i w innych częściach Europy, doświadczanie podróży po przełomie renesansowym w drastyczny sposób wpłynęło na literaturę. Spychanie w niepamięć tych doświadczeń zubaża naszą wiedzę o wielokulturowej, wielonarodowej i wielowyznaniowej tożsamości ówczesnego państwa polskiego. 
W tym kontekście nie sposób nie wspomnieć o jeszcze jednym ważnym tekście związanym ze staropolskim podróżowaniem, mającym silne związki ze społecznością czeskich emigrantów działających na terenach Wielkopolski, spełniającym postawiony przez Dziechcińską postulat emocjonalnego i sensualistycznego mówienia o samym sobie wyrastający z doświadczania odmiennej przyrody i odmiennych miejsc. Tekstem tym jest Islandia albo krótkie opisanie wyspy Islandyi Daniela Vettera. Udziałem i tego utworu stało się wieloletnie zapomnienie. Pierwsza europejska relacja z podróży na Islandię sporządzona przez Daniela Vettera w roku 1638 zachowała się do naszych czasów tylko w egzemplarzach unikatowych - zarówno w wersji polskojęzycznej, jak niemieckojęzycznej (Rott 2002, 112), można zatem powiedzieć, że o jej ocaleniu zadecydował taki sam przypadek jak ten, który pozwolił dotrwać do naszych czasów tekstom Jana Ryby i Jana Rybińskiego. Trudno nie oprzeć się wrażeniu, że tekst Vettera jest kolejnym w szeregu egodokumentów, które stały się częścią doświadczenia kulturowego odrzuconego na przestrzeni wieków przez polskich czytelników.

O tym, że odrzucenie to było przynajmniej w jakimś stopniu warunkowane obcością kulturową wynikająca z emigracyjnego charakteru autorów wydaje się świadczyć drugi po rodzinie Rybińskich przypadek, na którym chciałbym się skupić w niniejszym artykule.

Związany jest on z postacią Jana Lasickiego, polskiego wyznawcy kalwinizmu, który uległ fascynacji braćmi czeskimi do tego stopnia, że postanowił poświęcić im osobne dzieło historiograficzne. Sam Łasicki nie jest osobą specjalnie znaną w polskiej historii literatury, na co wpływ chyba największy miała specyficzna recepcja jego osiagnięć naukowych i pisarskich. Nie jest przypadkiem, że Henryk Barycz - autor jedynej polskiej monografii poświęconej Łasickiemu - jako powód jej powstania wymienia „fatum ciążące nad ta postacia. Po prostu Łasicki, jak nie miał szczęścia za życia, podobnie nie znalazł uznania w oczach potomności” (1973, 6), przy czym zauważa on równocześnie, że chodzi o jednego z ważniejszych intelektualistów polskich wieku XVI. Już we wstępie do swojej pracy zestawia go ze Stanisławem Hozjuszem, Andrzejem Fryczem Modrzewskim czy Janem Laskim (Barycz 1973, 5). Tym większym paradoksem jest dla niego fakt, że tak doskonała postać spotkała się z chłodnym odbiorem, i to zarówno na gruncie czeskim - Łasickiego krytykowała szkoła Jaroslava Golla (Barycz 1973, 7), jak i polskim, gdzie Łasicki został nazwany wręcz plagiatorem, co przez długi czas ciążyło nad recepcją niektórych jego dzieł: „roku 1580 był już [Łasicki] na Litwie, bo wtedy właśnie ukończył swe plagiaty" (Mierzyński 1870, 
10; podkr. - M.H.). Najbardziej paradoksalne są jednak losy historii braci czeskich, której autorem był Łasicki.

Książka ta - wypada zauważyć na wstępie - nigdy nie została opublikowana, a stan jej zachowania jest w zasadzie nieznany, mimo że istnieją przynajmniej trzy różne jej odpisy pochodzące z XVIII wieku. Z doktryną braci czeskich polski autor zetknął się stosunkowo wcześnie. Już w roku 1566 wspomina o Jednocie w liście do Teodora Bezy, uznając wielkopolskich braci czeskich za gwarancję ładu wyznaniowego w Wielkopolsce (por. Barycz 1973, 60). Rok później - kiedy zostanie nauczycielem synów wojewody inowrocławskiego, Krotoskiego - będzie miał okazję samodzielnie przekonać się, jak wygląda życie przedstawicieli Jednoty, między innymi w Łobżenicy, w której obowiązki seniora pełnił wówczas Jan Ryba. Ożywione kontakty ze środowiskami czeskich emigrantów sprawiły, że już w roku 1568 gotowa była pierwsza redakcja utworu zatytułowanego De orgine et institutis fratrum christianorum qui sunt in Prussia, Polonia, Bohemia et Moravia commentarius. W pracy nad nia pisarz korzystał z archiwaliów Jednoty, które udostępnione mu zostały pod warunkiem, że bez zgody Jednoty nie będzie publikował gotowego tekstu. Zgoda taka nie została jednak przez przedstawicieli braci czeskich nigdy wyrażona $\mathrm{i}$ to ani w wypadku tej pierwszej redakcji tekstu, która nie została nawet Łasickiemu zwrócona, ani też w przypadku redakcji drugiej, która gotowa była w roku 1585. Weszła ona - wbrew woli Łasickiego, który po prostu nigdy nie otrzymał z powrotem wysłanej kopii - w skład archiwum Jednoty przechowywanego w Lesznie i tam została odnaleziona przez najsłynniejszego bodaj czeskiego emigranta w Polsce - Jana Amosa Komeńskiego.

Wyrażając krytyczny stosunek do decyzji swych poprzedników, Komeński zdecydował się wydać przynajmniej fragment posiadanego rękopisu. W roku 1649 w Amsterdamie ukazał się drukiem fragment dzieła, którego historia zaczęła się niemal sto lat wcześniej. Paradoksem jest, że jedyna nowoczesna edycja tego polskiego tekstu ukazała się w roku 2013 jako część dziewiątego tomu dzieł wszystkich J.A. Komeńskiego. Za ironię historii można uznać fakt, iż ostatni senior czeskiej Jednoty, przebywajacy na emigracji, musiał w ten sposób ocalać od zapomnienia dorobek twórczy polskiego kalwina, który zafascynowany był początkową fazą funkcjonowania braci czeskich na polskich ziemiach. W tym sensie przekraczanie granic terytorialno-państwowych związane z emigracja jest - w odniesieniu do wieku XVII tak samo nieuchronne jak przekraczanie granic konfesyjnych.

Tym, co uderza dziś w postaci Łasickiego, jest jego sposób poznawania ówczesnego życia intelektualnego, który nie odbiega od tego, który w kon- 
tekście dzisiejszej sytuacji kulturowej postuluje Ryszard Nycz. Epistemologia wglądów - odczuwanie poznania jako zjawiska determinowanego czasowością i związana z tym świadomość bogactwa otaczającego poznający podmiot - wydaje się idealnym kontekstem dla sytuacji intelektualnej okresu reformacji. Nycz zauważa, że w momentach zmiany kulturowego paradygmatu

musimy porzucić klasycznie nowoczesną (...) procedurę badawczą opartą na założeniu obiektywności poznania z zewnętrznej perspektywy i przystać na badanie prowadzone od wewnątrz. Można powiedzieć, że scjentystyczne analizowanie zastępujemy przez sondowanie. $Z$ tego punktu widzenia kultura jest siecią działań i znaczeń, w których aktywnie uczestniczymy, kształtując je i podlegając ich oddziaływaniom $(2017,72)$.

Różnorodność punktów widzenia, z którymi stykał się Łasicki, wymuszała na nim funkcjonowanie w przestrzeni pozbawionej wyraźnego centrum. W tym sensie Łasicki odbiegał od osób jawnie opowiadających się za którąkolwiek z ówczesnych konfesji. Łasicki, choć z żalem obserwował konwersje swych przyjaciól, to jednak pozostawał otwarty nie tylko na ich światopogląd, ale również na wyrażaną przez nich argumentację. Chyba właśnie tak można tłumaczyć jego odejście od kalwińskiej ortodoksji, z którą miał kłopoty już w młodości.

W świecie intelektualnych konfliktów powstających na tle wyznaniowym czy wręcz otwartych wojen religijnych taka postawa nie mogła jednak liczyć na szersze zrozumienie. Nie dziwi więc, że dorobek Łasickiego w większej części został skazany na zapomnienie, zarówno przez braci czeskich, jak i przez Polaków. Te próby stworzenia historii czeskiej konfesji na ziemiach polskich zostały poddane cenzurze samej Jednoty. Paradoksem więc jest, że dorobek Łasickiego pomógł uratować chociażby w części czeski uchodźca, mający w swojej intelektualnej biografii doświadczenia z Czech, Moraw, Węgier i innych miejsc. Postrzeganie świata konfliktów religijnych przez Komeńskiego nie odbiegało od światopoglądu wyznawanego przez Łasickiego.

Omawiając skomplikowane losy tekstu Lasickiego o braciach czeskich, nie sposób nie wrócić jeszcze raz do rodziny Rybińskich. Los, który spotkał historiograficzną pracę Łasickiego, do pewnego stopnia przypomina bowiem historię tekstu, który wyszedł spod pióra innego jeszcze niż Jan Ryba i Jan Rybiński członka tej rodziny. Maciej Rybiński do historii literatury wszedł jednym w zasadzie tylko dziełem - przekładem psalmów, który po raz pierwszy ukazał się w roku 1605 pod tytułem Psalmy Dawidowe... na melodie psalmów francuskich urobione. Psalmy te stały się w środowiskach protestanc- 
kich na tyle popularne, że przekład Macieja Rybińskiego zaczęto włączać do różnego typu modlitewników i kancjonałów o charakterze kompilacyjnym. Najważniejszym z takich tekstów stał się kancjonał wydawany w Toruniu w roku 1611 zatytułowany Cantional pieśni duchownych i psalmów śmietych, którego wszakże nie należy utożsamiać ze słynnym kancjonałem toruńskim Piotra Artomiusza (o kłopotach związanych z polskimi kancjonałami szerzej pisze m.in. Karolina Smolarek - por. Smolarek 2014).

Siła oddziaływania tego kancjonału okazała się większa niż samodzielnie wydawanych psalmów Macieja Rybińskiego, choć i ta autorska całość wydawana była dość często (kolejne edycje rejestrowane przez Nowy Korbut pochodzą z lat: 1608, 1616, 1617, 1618, 1619, 1624, 1628, 1630 i dalej). Wydany w Toruniu kancjonał legł u podstaw całej rodziny tekstów. W 1636 ukazał się Cantional to jest ksiegi psalmów, hymnów i pieśni duchownych opracowany przez związanego z Jednota Jana Turnowskiego, co tłumaczy, dlaczego do tego zbioru trafiły również psalmy w tłumaczeniu Rybińskiego. W efekcie interferencji różnych wydań udział Macieja Rybińskiego w tych inicjatywach stał się niemal całkowicie niewidoczny i w tym sensie jego dorobek literacki spotkało stopniowe zapomnienie, które tym razem nie było nawet celowym działaniem, ale wynikało z faktu, że różne wersje kancjonałów przytaczały lub pomijały całkowicie psalmy Rybińskiego. Jego dorobek literacki nie zaginął więc całkowicie - poszczególne utwory dałoby się wydzielić i dokonać ich atrybucji, ale do dziś nikt się o taką próbę nie pokusił, podobnie zresztą jak o sprawdzenie, czy tłumaczenia Rybińskiego nie weszły do innych wówczas powstających kancjonałów.

W efekcie tego długotrwałego procesu doszło jednak do sytuacji paradoksalnej, w której autor pierwotnego tłumaczenia praktycznie całkowicie zniknął ze świadomości odbiorców tych zbiorów. Postać syna czeskiego emigranta „rozpuściła się” w tradycji tekstowej kancjonałów protestanckich do tego stopnia, że dziś Maciej Rybiński jest pomijany praktycznie przez wszystkie syntezy polskiej literatury. W tym sensie historia recepcji jego dorobku twórczego jest nie tylko historią zapominania o autorze przekładu, ale również zanikania tradycji braci czeskich w polskim życiu literackim. Tekst Macieja Rybińskiego uległ takiemu samemu rozproszeniu w cudzych osiągnięciach literackich jak tekst Łasickiego, którego - w przeciwieństwie do Komeńskiego - nie zna prawie nikt. Podobnie rzecz się ma z Maciejem Rybińskim - postać ta istnieje w zasadzie wyłącznie poprzez teksty, które pomijają atrybucję przekładów jego autorstwa, choć zbiory, w których przekłady te się ukazywały, znane były szerokiemu kręgowi odbiorców. 
Tych łączników pomiędzy losem Łasickiego a przedstawicielami rodziny Rybińskich jest zresztą więcej, co wyraźnie wskazuje na sieciową strukturę powiązań łączących nie tylko ich samych, ale również całe środowisko związane z braćmi czeskimi i czeską emigracją w Wielkopolsce. Najpiękniejszym z nich pozostaje elegia X ze zbioru Jana Rybińskiego. Jest to utwór o charakterze valety - pożegnania wyrażonego wprost w końcowych partiach wiersza: Niechaj wam stużq wiernie koła, wóz, woźnica, / Koń silny, dzień pogodny i gospodarz. mity. / Rzektbym wiecej, lecz, pora zwiezłym kończyć stowem, / Które dobre życzenia zwykto końcayć: ;́gnaj! (Rybiński 2015, 85), a skierowanego do Jana Lasickiego, który wyjeżdżał wówczas z Wrocławia do Strasburga.

Po tym literackim pożegnaniu Łasicki udał się w swoją ostatnia, jak pokazał czas, podróż zagraniczną. Po jej zakończeniu osiadł w Wilnie i stopniowo wycofywał się z czynnego życia intelektualnego ówczesnej Europy, skupiając się głównie na prowadzeniu polemik z wileńskimi jezuitami (choć nie tylko wileńskimi, bo z tego późnego okresu zachowała się np. polemika Łasickiego z Possevinem). Z kolei dla Jana Rybińskiego był to dopiero początek zarówno przygód intelektualnych, które zawiodą go do Gdańska, Pragi, Strasburga czy Heidelbergu, jak i jego drogi twórczej. To dwie historie - spolonizowanego już niemal w drugim pokoleniu przedstawiciela czeskiej emigracji oraz dojrzałego intelektualisty, który część życia poświęcił na opis konfesji, którą ten pierwszy reprezentował. Punktów stycznych w tych biografiach jest zbyt wiele, by można było mówić o zbiegach okoliczności czy przypadkach. Epistemologiczny wymiar podróżowania widoczny u Łasickiego i Rybińskiego nie może w ogóle dziwić. Dla środowisk braci czeskich na terenach Rzeczpospolitej mitem założycielskim była tradycja emigracji i świadectw piśmienniczych z ową emigracją związanych. W zachowanych rękopisach braci czeskich wątek niebezpiecznej podróży, a w zasadzie ucieczki, nawiązywał w sposób mniej lub bardziej świadomy do topiki homo viatori tę tradycję kontynuowały środowiska Jednoty.

Te dwie $-z$ punktu widzenia szeregów literatur narodowych marginalne jednak - historie pełne są podróży i kontaktów intelektualnych, czyli mobilności rozumianej zarówno dosłownie, jak i metaforycznie. Wydaje się to do pewnego stopnia zrozumiałe - wszak emigracja jest wymuszona mobilnością, a ciało raz puszczone w ruch może w owym ruchu pozostać długo, zależnie od okoliczności zewnętrznych. Na końcu wieku XVI i w początkach stulecia następnego okoliczności w ewidentny sposób sprzyjały takiemu właśnie trybowi życia. Jednym z niekwestionowanych aspektów, o które czeska emigracja wzbogaciła ziemiańską kulturę Rzeczpospolitej była właśnie owa nadzwyczajna mobilność. 
Znamienne jest przy tym, że owe emigracyjne podróże kształtują w specyficzny sposób polską literaturę od strony genologicznej, na co starałem się już wcześniej zwrócić uwagę. Tradycyjne spojrzenie na piśmiennictwo tej epoki nakazuje nam widzieć na przełomie XVI i XVII wieku pewne konkretne zjawiska estetyczne wywodzące się zazwyczaj jeszcze z tradycji renesansowej. Taki model lekturowy wprowadził Ziomek do cytowanej wcześniej krytycznej oceny dorobku Rybińskiego. Pieśni ze zbioru Gésli różnorodnych są przykładem nieudanego horacjanizmu i naśladowania pieśni Kochanowskiego, mieszczą się jednak w utrwalonym postrzeganiu systemu genologicznego i dlatego można dokonać ich estetycznej oceny. Elegie podróżne tego samego autora już nie spełniały tego warunku. $\mathrm{Na}$ ich wydanie wypadło czekać polskiemu czytelnikowi aż do początków XXI wieku, ponieważ wcześniej nie było w zasadzie wiadomo, z jakim typem tekstu mamy w ich wypadku do czynienia. Próba klasyfikacji genologicznej tego tekstu została dokonana dopiero przez Romana Krzywego (Krzywy 2001, 107-109), który zreszta wraz z Elwirą Buszewicz - odegrał kluczowa rolę w wydaniu całego zbioru.

Wczesnonowożytne polskie egodokumenty - czego dowodzi korpus tekstów związanych z czeską emigracją w Rzeczpospolitej - sa grupa znacznie obszerniejszą i zróżnicowaną, niż mogłoby się wydawać. Oprócz wspomnianych już do tej pory tekstów można by do nich zaliczyć „sztambuch Łasickiego[który - M.H.] stanowi pierwszy ślad przyjęcia się u nas tej wchodzącej w życie na Zachodzie formy upamiętnienia spotkań i nawiązanych znajomości” (Barycz 1973, 13). Łasicki ma się odróżniać od większości ówczesnych polskich podróżników, którzy wobec kultur poznawanych w czasach peregrynacji ,zachowywali przeważnie stanowisko bierne, receptywne wobec zjawisk kulturowych (...) i tworzyli swoiste getta za granica, trzymając się razem oraz kultywując styl życia i obyczaj narodowy" (Barycz 1973, 13).

Omawiane w niniejszym szkicu teksty w żaden sposób nie zmienią kanonu polskiej literatury - większość z nich ma poważne wady natury estetycznej. Historia literatury to jednak nie tylko historia arcydzieł, ale również szeroko rozumianych inspiracji intelektualnych. Tak długo, jak nie spojrzymy na dorobek literacki czeskiej emigracji w Polsce, tak długo nie będziemy w stanie należycie docenić takich postaci, jak Rybiński czy Łasicki. Literaturę polską wieku XVII zwyczajowo już chcemy oceniać przez pryzmat baroku ziemiańskiego i sarmatyzmu. Przynajmniej w pierwszej połowie tego stulecia możemy jednak obserwować niesamowitą dynamikę literackich form związanych z doświadczeniem podróży oraz form autobiograficznych, które w dużej mierze sa wynikiem otwartego i tolerancyjnego charakteru ówczesnego 
polsko-litewskiego modelu życia intelektualnego. Przyjmowanie emigrantów przekładało się na modyfikowanie i wzbogacanie kultury rodzimej, która stawała się dzięki temu bardziej różnorodna. Procesy odwrotne - ujednolicanie i zamykanie - cechujące Rzeczpospolitą w drugiej połowie wieku XVII doprowadziły nie tylko do namacalnego wygnania czeskich różnowierców, czego symbolem stało się Lesnae excidium, ale również do wykluczenia ze świadomości kulturowej tych form literackich, o które emigranci wzbogacili polską kulturę. Oczywiście, jak każdy sąd uogólniający, również i ten może być poddany w wattpliwość, jednak losy spuścizny literackiej Rybińskich czy Łasickiego wydają się potwierdzać słuszność takiego wnioskowania. Literatura wzbogacana przez zewnętrzne nurty intelektualne przejawia większą różnorodność i żywotność niż formacje zamknięte. I w tym sensie poznanie emigracji staje się równocześnie samopoznaniem.

\section{Literatura}

Akta synodón różnowiercsych w Polsce, 1963-1997, oprac. M. Sipayłło, Warszawa.

Barycz H., 1973, Jan Lasicki. Studium z dziejón polskiej kultury naukowej XVI wieku, Wrocław.

Bidlo J., 1900-1933, Jednota bratrská v prunim vyhnanství, t.1-4, Praha.

Buszewicz E., 2015, wstęp do: Rybiński J., Ksiega elegii podróżnych, Warszawa.

Dekker R., 2002, Jacques Presser's Heritage: Egodocuments in the Study of History, „Memoria y Civilización", no. 5.

Dworzaczkowa J., 2003, Szkoła w Lesznie do roku 1656: nauczyciele i programy, Leszno.

Dworzaczkowa J., 1997, Bracia czescy w Wielkopolsce w XVI i XVII wieku, Warszawa.

Dworzaczkowa J., 1995, Reformacja i kontrreformacja w Wielkopolsce, Poznań.

Dziechcińska H., 2003, Świat i čltowiek w pamietnikeach trzech stuleci: XVIXVIIXVIII, Warszawa.

Gmiterek H., 1989, Zwiazki intelektualne polsko - czeskie w okresie Odrodzenia (1526-1620), Lublin.

Krzywy R., 2001, Od hodoeporikonu do eposu peregrynackiego. Studium z historii form literackich, Warszawa.

Łukaszewicz J., 1835, O kościołach braci czeskeich w dawnej Wielkopolsce, Poznań.

Magnuszewski J., 1977, Literatura polska a literatura czeska do połony XVIII wieku, w: Ślaski J.,

Michałowska T., red., Literatura staropolska w kontekście europejskim, Wrocław.

Mierzyński A., 1870, Jan Łasicki, šródto do mitologii litenskeiej, Kraków.

Nowak Z., Świderska A., 1968, wstęp do: Rybiński J., Wiersze polskie, Poznań.

Nycz R., 2017, Kultura jako czasownik. Sondowanie nowej bumanistyki, Warszawa.

Rott D., 2002, Bracia czescy w dawnej Polsce. Driatalność literacka - teksty - recepcja, Katowice.

Rybiński J., 2015, Ksiega elegii podró̇nych, Warszawa.

Rytel J., 1962, „Pamietniki” Paska na tle pamietnikarstwa staropolskiego. S₹̌kic z driejów prosy narracyjnej, Wrocław.

Sajkowski A., 2007, Sarmackie tradycje i europejskie horyzonty, Poznań. 
Smolarek K., 2014, Piotr Artomiusz i jego kancjonat toruński z końca XVI wieku, „Rocznik Toruński”, t. 41.

Śliziński J., 1959, Z działalności literackiej braci czeskich w Polsce (XVIXVII wiek), Warszawa.

Tazbir J., 2010, Państwo bez stosów. Szkice z driejów tolerancji w Polsce w XV TXVII w., Warszawa.

Ziomek J., 1995, Renesans, Warszawa.

Ziomek J., 1990, Retoryka opisowa, Warszawa. 